\title{
Inequality and economic marginalisation: How the structure of the economy impacts on opportunities on the margins
}

\author{
KATE PHILIP \\ Programme Manager: Inequality and Economic Marginalisation, Trade and Industrial Policy \\ Strategies (TIPS)
}

\section{BEYOND THE “SECOND ECONOMY” DEBATE}

It's a truism that to change the world you have to understand it. This is why debate over the notion that South Africa has "two economies" became so heated: because of how this concept informed development strategy.

The description of South Africa as characterised by a "first economy" and a "second economy" entered policy debate following the use of the terms by President Thabo Mbeki in an address to the National Council of Provinces in November 2003. He described the second economy as follows:

"The second economy (or the marginalised economy) is characterised by underdevelopment, contributes little to GDP, contains a large percentage of our population, incorporates the poorest of our rural and urban poor, is structurally disconnected from both the first and the global economy, and is incapable of self-generated growth and development." 1

The concept of South Africa's "two economies" became widely used, particularly in government, but was regarded with some scepticism in left-wing academic and policy circles. It soon became clear that the concerns were not immaterial. Too literal an interpretation of the notion of "two economies" leads down deeply flawed paths in policy terms - too easily underpinning an approach that sees the first economy as representing the benchmark for how things should be - with the goal of policies targeting the second economy being to assist it to "catch up". So, the "first economy" is the solution, the "second economy" is the problem.

So, for example, when the Accelerated Shared Growth Initiative of South Africa (AsgiSA) was announced by Deputy President Phumzile Mlambo-Nguka in February 2006, its aims included "eliminating the second economy."

\footnotetext{
1 President Thabo Mbeki, Address to the National Council of Provinces, November 2003, as quoted in Devey, R. \& Valodia, I "Formal-informal economy linkages: what implications for poverty in South Africa?" (2009) PLAAS Working Paper 8.
} 
A key feature of deep inequality, however, is that both ends of the spectrum are a form of distortion, and it is not just the disadvantaged end that is unsustainable as a norm for an inclusive society.

At the most obvious level, this is manifest in the way conspicuous consumption at the elite end of the "first economy" informs wider expectations and aspirations while at the same time fuelling discontent not only amongst the very poor, but also amongst people whose lives may in fact be improving but only in modest ways. The scope for a sense of relative deprivation to mobilise popular resentment was one of the strands in the internal battles in the ruling party at the ANC's 2007 Polokwane Conference - as reflected in the following headline in Business Day during the Conference:

“'Less Bling' Pleads Joel Netshitenzhe". ${ }^{2}$

At the next level, a focus on strategies for the second economy that aim to make it become more like the first economy are easily aligned with policy approaches that see no real connection between the current patterns and structures of ownership and accumulation in the economy and the incidence of poverty, and therefore no necessary connection between anti-poverty strategies and a need for change in these patterns and structures: in other words, no necessary connection between addressing poverty and a need to effect change in patterns of distribution, beyond change in the racial demographics of ownership within the existing economic structure. In policy terms, this has meant that rampant accumulation within the "first economy" is not seen as being in any real tension with the anti-poverty strategies being advocated for the second economy; nor is it recognised that the "second economy" is in many respects a consequence of the forms of accumulation in the "first economy", nor that the existence of the "first economy" depends in part at least on the continued existence of the "second economy".

The growing policy emphasis on the need for "inclusive growth" rather than just any growth reflects these different perspectives. Tregenna and Tsela demonstrate that, without changes in distribution, the goal of halving poverty by 2014 could not be achieved within the growth targets that pertained at the time without complementary shifts in distribution - and that was before the financial crisis. ${ }^{3}$ An effective anti-poverty strategy cannot avoid tackling the issue of distribution.

The second key area of critique of the concept of "two economies" is the idea that there is a "structural disconnection" between them, that they operate in parallel, with the second economy left out, left behind, undeveloped and excluded from economic opportunities because it is disconnected.

The world around us certainly appears to validate such an analysis: Diepsloot and Sandton appear worlds apart - more so Matatiele and Cape Town. The dichotomies between them are manifested spatially as well as at the level of outcomes in relation to access, capabilities and opportunities. These dichotomies at the level of outcomes are, however, too easily understood as also reflecting a disconnection at the level of process despite a history in which the processes of dispossession, extraction and exploitation are

\footnotetext{
2 Business Day 21 December 2007.

3 Tregenna, F \& Tsela, M “Inequality, Unemployment and Poverty in South Africa" Second Economy Strategy Project, Trade and Industrial Policy Strategies (TIPS) (2009).
} 
all too clear. It is this gulf - this apparent disconnection - between the outcomes at each end of the spectrum of inequality that makes the idea of two "disconnected" economies side by side appear intuitively correct.

The focus of critical analysis of the concept was therefore on making these processes and the inter-relationships between South Africa's advanced development and its high levels of economic disadvantage more visible, and on developing the concepts to describe them. For example, Du Toit and Neves characterised the relationship as one of "adverse incorporation," to highlight the extent to which poverty and economic marginalisation are as much a function of incorporation and integration into the economy on adverse terms as a result of exclusion from it. ${ }^{4}$ Von Holdt and Webster characterised the relationship of first and second economies as one of "asymmetrical interdependence". ${ }^{5}$ Research by Valodia, Devey and Skinner traced the many forms of linkages and interdependencies between the formal and informal economies, including product linkages such as the sale of branded goods by street-traders. ${ }^{6}$ Du Toit and Neves also highlight the "echoes" of this discourse in international debate:

“'(S)econd economy' talk draws on habits of thought and unreflectively held assumptions that are more broadly shared within the discourses of development and globalisation, particularly those that relate to notions of 'social exclusion' or to the links between global integration, growth, inequality and poverty." 7

In July 2007, against the backdrop of this discourse, the Presidency commissioned a review of the performance of existing programmes targeting the "second economy", as well as a strategy process to recommend how outcomes "in" the second economy could be strengthened. Despite terms of reference that took the concept of the second economy for granted, this strategy process attempted to engage in an open way with the then-raging debate around the use of the term, from a perspective that assumed the policy purpose was to focus on the challenges of poverty and economic marginalisation, and to understand these better in order to change them. The key outcomes of this process are summarised in a document ${ }^{8}$ (hereafter referred to as the "Strategic Framework") that was approved by Cabinet in January 2009, and then included in full in the final report of the Presidency's Accelerated Shared Growth Initiative of South Africa (AsgiSA).

This Strategic Framework argued that what are described as the "first" and "second" economies are not disconnected but are manifestations of high inequality, and that this inequality is deeply structural and is rooted in key legacies of apartheid. This analysis has a range of key implications for strategy, and concludes with a set of headline strategies.

While the second economy strategy process began under Thabo Mbeki's Presidency, its outcomes were approved under President Kgalema Motlanthe, in the "interregnum"

\footnotetext{
${ }^{4}$ Du Toit A, \& Neves D. "In Search of South Africa's Second Economy" (2007) 37(2) Africanus.

${ }_{5}^{5}$ Von Holdt K, \& Webster E. "Work Restructuring and the Crisis of Social Reproduction: A Southern Perspective" in Webster, E. \& Von Holdt, K Beyond the Apartheid Workplace: Studies in Transition edited by. KwaZulu-Natal Press (2005).

${ }^{6}$ Devey \& Valodia (2009) n 1 above.

${ }^{7}$ Du Toit \& Neves (2007) n 4 above

8 Second Economy Strategy Project, "Second Economy Strategy: Addressing Inequality and Economic Marginalisation: A Strategic Framework" TIPS (2009); commissioned by the Presidency.
} 
between the Mbeki era and the advent of the Zuma Presidency. ${ }^{9}$ Since then, the notion of the "second economy" has declined in visibility.

Why then revisit these debates here?

There are two main reasons for doing so.

Firstly, because many people in government (and outside of it) still use the term uncritically.

Secondly, the kinds of development strategies that arose as a consequence of the logic of "two economies" remain largely intact. Despite potentially important shifts in government policy over this period, the strategic implications of understanding economic marginalisation as a function of structural inequality have not percolated very far, inside or outside of government. Yet it really matters for development policy that they should do so. The focus of this article is on trying to take this aspect of the debate further; because whatever term is used to describe the complex set of conditions that add up to economic marginalisation, an understanding of these conditions is key to development strategy.

\section{ECONOMIC MARGINALISATION: ROOTED IN STRUCTURAL INEQUALITY}

The central argument in the Strategic Framework is that structural inequality in South Africa has its origins in the following key legacies of apartheid:

- the structure of the economy: the centralised, monopoly structure of the core economy, the highly skewed distribution of assets such as land and capital, and the impacts of migrant labour;

- the spatial legacy of bantustans and apartheid cities;

- the deep inequalities in the development of human resources.

Despite the many changes in South African society since 1994, these forms of structural inequality continue to hamper the best efforts of development policy, reinforcing old forms of economic marginalisation at the same time as facilitating new ones. The combined effect of these different forms of structural inequality (depicted in Figure 1 below) is to create and maintain deep levels of economic marginalisation that lock people into poverty, with each of these dimensions compounding the impacts of the next. For the purposes of this article, the interface between the structure of the economy and issues of spatial inequality is particularly key; it isn't really possible to understand the nature of economic marginalisation in South Africa without understanding this history - and in fact, the debates over this history prefigure the "second economy" debate in certain respects.

\footnotetext{
9 The author headed this strategy process for the Presidency. The analysis presented in this article draws from - and builds on - this work.
} 
Figure 1: Structural Inequality and Economic Marginalisation ${ }^{10}$

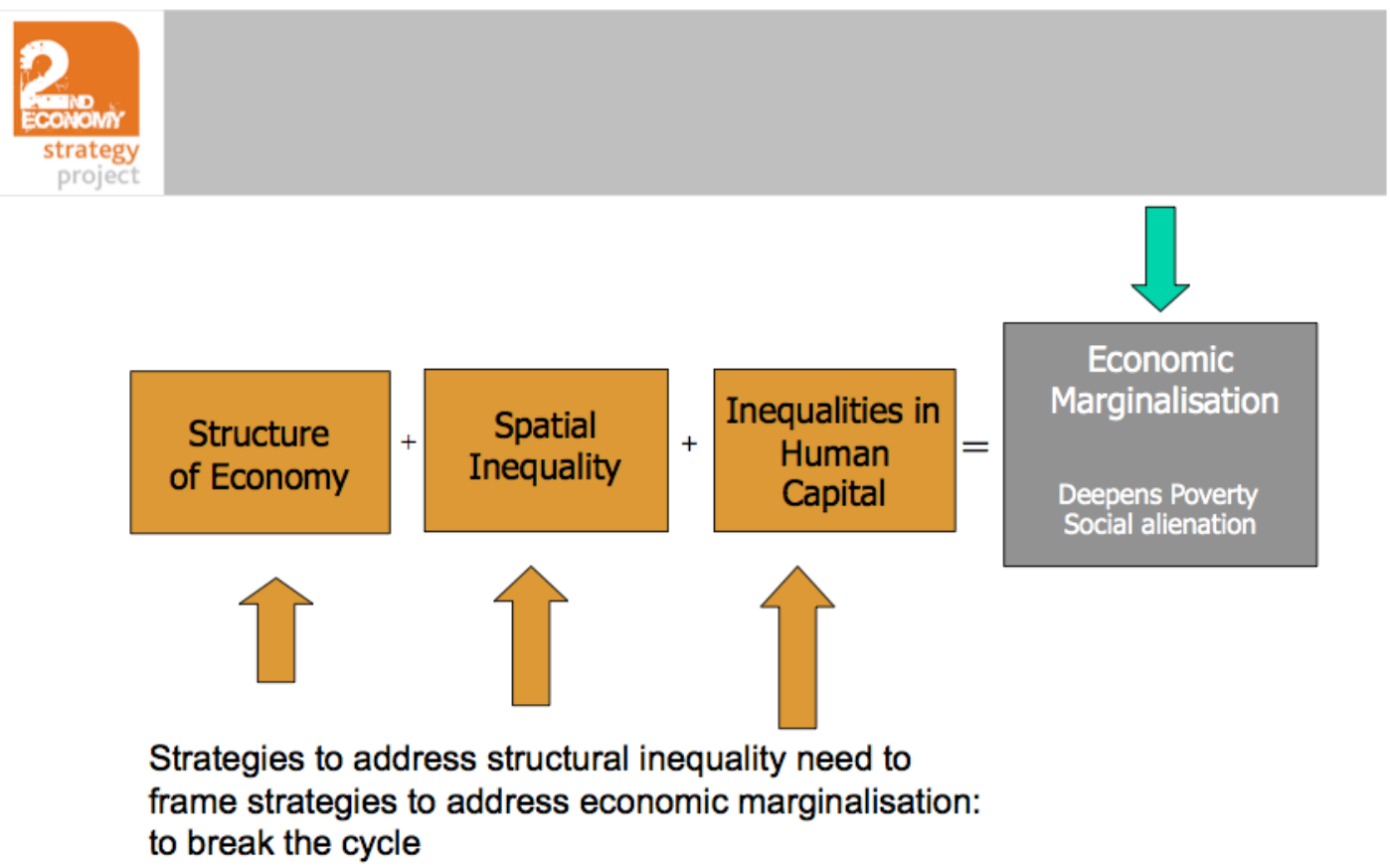

In the 1970s the concept of "dual economy" was used to describe South African society, with this "dualism" presented as a conflict between two modes of production: a precapitalist one in the "reserves" (which became the bantustans) and an advanced capitalist one in the rest of the country. Harold Wolpe and Martin Legassick critiqued this concept, highlighting instead the role of the 1913 Land Act through which the "native reserves" were first promulgated. The 1913 Land Act forced [mainly male] black South Africans off the land and into the labour market, creating a cheap migrant labour force for South Africa's mines. At the same time subsistence production, women's productive labour and unpaid care work in the reserves all contributed to household subsistence in rural areas in ways that - initially at least - subsidised low wages on the mines and in urban areas. ${ }^{11}$

Far from institutionalising a dual economy in which pre-capitalist and capitalist systems of production could be mapped neatly onto the spatial boundaries of the system of "separate development" (then still under construction), the 1913 Land Act instead linked the politics and economics of land and labour - and, in the process, of spatial and economic development - in ways that have shaped South African society and its economy in profound ways ever since.

The creation of the bantustans underpinned the core logic of apartheid's "separate development", with the pass laws enforcing patterns of migrancy intended to ensure that black men came to work in the mines and factories in "white" South Africa, and a smaller

\footnotetext{
10 Philip, K "Inequality and Economic Marginalisation" Paper presented to Plaas Conference "Working on the Margins" (March 2009).

11 Wolpe, H. "Capitalism and Cheap Labour Power in South Africa: From Segregation to Apartheid" (1972) 1

(4) Economy and Society.

Legassick, M. "South Africa: Capital Accumulation and Violence" (1974) 3 (3) Economy and Society.
} 
cohort of women migrating to work in white homes as domestic workers. Neither had rights to settle permanently in the cities and towns: a denial of citizenship that, taken to its most absurd, saw bantustans like Bophutatswana and the Transkei issuing their own "passports."

The legacies of these linked logics of dispossession, "separate development", labour migrancy and urban transience bedevil rural and agrarian development to this day. They had equally profound impacts on the space economy in urban areas. Black townships in "white" areas were designed with the express intent of limiting the scope for residents to put down roots or build communities; they were designed as places with no internal social or economic logic, as dormitory towns, with some of the housing taking the form of singlesex hostels. They were places where business activity was largely disallowed, built at a distance from the white cities and towns but dependant on them for work, for social services, and even for basic retail facilities.

Even in the apartheid years this logic began to break down, driven in part by resistance, but also by shifts in labour demand that required more skilled workers and therefore a more permanent urban workforce. With growing urbanisation townships grew, and so did informal settlements, often trying to circumvent the spatial illogic of apartheid cities by setting up shacks closer to economic opportunities.

This legacy of spatial "apartheid" - of being apart - imposed structures of spatial distance on the society and the economy that are still so visible - and so real - that they easily mask the complex sets of relationships that deliver both wealth and poverty within a single economy.

\section{HOW THE STRUCTURE OF THE ECONOMY IMPACTS ON SMALL-SCALE MANUFACTURING AND AGRO-PROCESSING}

Each of the three pillars of structural inequality, described above, plays its own part in embedding economic marginalisation. The focus of this paper is, however, mainly on one of these: on how the structure of the economy impacts on economic opportunities on the margins and what that means for development strategy.

The key characteristics of the core economy are well understood: the "commanding heights" of South Africa's economy are highly centralised, with high levels of concentration of capital and limited levels of competition in key sectors. Capital-intensive industries tend to exclude participation by small enterprises and make employment creation expensive. The negative impacts of this economic structure on job creation and also on small enterprise development in the core economy are relatively well understood. However, the extent to which this economic structure constrains options and opportunities on the margins - including for subsistence and livelihood activities - is often overlooked.

Yet this is key to understanding what is otherwise a policy conundrum in South Africa: the small scale of its micro-enterprise and informal sectors, given the context of high unemployment. The informal sector comprises only 17 percent of total (non-agricultural) 
employment. ${ }^{12}$ The relatively small scale of this sector is considered surprising, given the high levels of unemployment; success rates and returns are low.

The Finscope Small Business Survey 2010 includes all forms of small business, formal and informal. Small business is defined as any business employing less than 200 people. The Survey finds that 83 percent of small businesses are not registered; that 79 percent of all small business-owners are traders; and that, of these, 62 percent "sell their products in the same form they bought them (they do not add any value)". ${ }^{13}$

The explanations for the relatively small scale of the micro-enterprise and informal sector, for the dominance of retail activity and for the low returns associated with the sector typically attribute this to lack of skills, constraints on access to credit, regulatory constraints on small enterprise development, a history of exclusion of black people from many categories of business under apartheid and the resultant lack of a "culture of entrepreneurship." Important as all these may be, what is missing from the list is recognition of the way the structure of the South African economy limits the scope for viable small enterprise in poor local economies and in rural areas and, in particular, for the kinds of manufacturing enterprise that offer the easiest entry points into the economy for new entrepreneurs.

For new entrepreneurs it is local markets that provide the easiest point of access into economic activity. This is because such markets are familiar, entrepreneurs can readily identify the opportunities within them, they understand the "value proposition", transport costs are kept low, transactions are usually directly with the end-consumer, and may draw on trust relationships within social networks. All of this makes a high level of informality possible, which in turn simplifies entry requirements. ${ }^{14}$

As a result, enterprise development strategies have often promoted models that target consumers in the local community in which the enterprise is operating. With the bias towards manufacturing evident in many small enterprise strategies, such approaches can be characterised as "local production for local consumption," in which priority is given to the production of basic consumption goods targeting consumers who typically have little disposable income. This goes hand in hand with an analysis that, quite correctly, sees it as problematic that money circulates so little in poor local economies before it returns to the more developed end of the economy, and aims to enhance the local content of local spending. High hopes have been pinned on the potential for such strategies to create jobs.

However, in poor communities markets are relatively "thin"; there is not a lot of money available to spend, and consumers buy a relatively limited range of goods and services. The

12 Statistics South Africa "Quarterly Labour Force Survey, Quarter 4, 2010" available at http://www.statssa.gov.za/qlfs/index.asp (accessed 11 June 2011).

13 Finmark Trust "Finscope South Africa Small Business Survey 2010" available at http://www.finscope.co.za/new/pages/Initiatives/Countries/South-Africa.aspx?randomID=d29cd5ff-c7614d12-ac33-99f522c0cc44\&linkPath=3 1\&IID=3 1 111 (accessed 11 June 2011).

${ }_{14}$ Philip, K "Enterprise on the Margins: Making Markets work for the Poor?" PhD Thesis, University of the Witwatersrand (2007). 
poorer the household, the greater the percentage of the household budget that will be spent on food, with 70.8 percent spent on food by those in the poorest decile. ${ }^{15}$

In rural areas, this expenditure on food appears to be a market opportunity for smallscale agricultural producers, particularly in a context in which many people in rural areas buy fresh produce rather than producing it - and, in relation to fresh produce in particular, opportunities certainly do exist. At the same time, however, the kinds of ruptures in access to land have led to very different trajectories of agricultural development in South Africa: in the former "white" areas commercial farming on a big-farm model dominates; in the former bantustans, where poverty is most concentrated, a process of de-agrarianisation has taken place instead:

"[In the commercial farming areas] there have been decades of investment - including substantial subsidies - into the development of a 'big farm' model and the institutions required to support it: including access to land, water, inputs, credit, business services, infrastructure, and market access - as well as opportunities to share in the development of an increasingly vertically-integrated agro-processing sector.

"In the former bantustans, however, these processes were mirrored by their opposites: those attempting to engage in agricultural production on increasingly small plots of land were not supported by the development of any of the institutions required to make a small-farm model viable. These two agricultural development paths still co-exist in an uneasy relationship."16

In the bantustans, increasing pressure on land led to declining plot sizes, to land degradation and declining returns from investment. At the same time rising demand for labour in urban areas, coupled with rising wages during the 1980s and 1990s, meant the returns from migrancy far outstripped the incomes that could be earned from the land, incentivising patterns of investment in migrancy rather than in agriculture, and fuelling existing processes of "de-agrarianisation" in former bantustan areas.

These continued processes of "de-agrarianisation" and rising dependence of rural households on non-agricultural income sources are reflected in Table 1 (below). According to the Labour Force Survey, an average of less than 50 percent of rural households participated in agriculture during this period; the table below provides the reasons given for their participation. Aliber sums up the process as follows:

“(0)ver the three years between September 2000 and March 2004, there has been a remarkably steady trend whereby the proportion of people who farm to provide the main source of food has declined in favour of the proportion of those who farm to produce an extra source of food." 17

As striking is that by March 2004, only 1.1 percent of those participating in agriculture earned their main income from it, and only 2.8 percent earned any additional income from agriculture.

\footnotetext{
15 Martins JH “Household Cash Expenditure by Livings Standards Measure Group” (2006) 34 Journal of Family Ecology and Consumer Sciences 1.

16 Philip K "Second Economy Strategy: Addressing Inequality and Economic Marginalisation" (2010) 37 New Agenda, Institute for African Alternatives, Cape Town.

${ }^{17}$ Aliber M. "Synthesis and Conclusions" (2005) in Aliber M., de Swardt C., du Toit A., Mbhele T \& Mthethwa T Trends and Policy Challenges in the Rural Economy (2005) HRSC Press.
} 
Table 1: Reasons for engaging in agriculture (percentages) ${ }^{18}$

\begin{tabular}{lllllll}
\hline Survey & $\begin{array}{l}\text { As a main } \\
\text { source of } \\
\text { food for the } \\
\text { household }\end{array}$ & $\begin{array}{l}\text { As the main } \\
\text { source of } \\
\text { income/ } \\
\text { earning a } \\
\text { living }\end{array}$ & $\begin{array}{l}\text { As an extra } \\
\text { source of } \\
\text { income }\end{array}$ & $\begin{array}{l}\text { As an extra } \\
\text { source of } \\
\text { food for the } \\
\text { household }\end{array}$ & $\begin{array}{l}\text { As a leisure } \\
\text { activity or } \\
\text { hobby }\end{array}$ & Total \\
\hline 2000, Sept. & 32.9 & 3.3 & 5.3 & 54.4 & 4.2 & 100.0 \\
\hline 2001 , Feb. & 24.2 & 2.7 & 3.7 & 67.0 & 2.5 & 100.0 \\
\hline 2001 , Sept. & 18.5 & 1.9 & 3.7 & 73.6 & 2.3 & 100.0 \\
\hline 2002 , Feb. & 14.3 & 1.4 & 2.6 & 80.1 & 1.6 & 100.0 \\
\hline 2002, Sept. & 11.4 & 1.7 & 3.2 & 81.6 & 2.1 & 100.0 \\
\hline 2003 , Mar. & 11.2 & 1.4 & 3.3 & 82.3 & 1.9 & 100.0 \\
\hline 2003 , Sept. & 5.2 & 1.9 & 3.4 & 87.7 & 1.7 & 100.0 \\
\hline 2004 , Mar. & 6.3 & 1.1 & 2.8 & 88.3 & 1.5 & 100.0 \\
\hline
\end{tabular}

Source: Labour Force Survey 2-9.

South Africa's experience in this respect is in sharp contrast to many other developing countries, where continued access to land provides a form of safety-net as well as a stepping stone into markets: subsistence agriculture provides a basic level of food security, surplus production offers an easy entry point into local fresh produce markets, and surplus production above this level provides the basis to enhance local economic development through entry into agro-processing and expansion to markets beyond the local economy, to serve growing urban demand for food.

The shift from subsistence production into surplus production, and from there into agroprocessing are such key stages in economic development that they have been the focus of many enterprise development strategies in rural areas: moving smallholder producers up the value chain into agro-processing in order to enhance farm incomes and to reach beyond local markets into growing urban markets also.

In South Africa, however, a range of constraints have limited this trajectory. Firstly, at the most basic level, a shift into agro-processing assumes a certain scale of surplus agricultural production but, as Table 1 illustrates, most households that are engaged in any kind of agricultural production are doing so for their own consumption; only a small percentage produce surpluses for sale.

Research from Mount Frere provides an example of how this manifests in a local economy:

${ }^{18}$ From Aliber M. in Aliber et al (n 17 above). 
"(F)or a vast majority of households that are involved in agriculture, food production plays only a supplementary role: $87 \%$ of households report that they are dependent on store bought maize meal all year round, while only $5 \%$ report that they can produce enough maize for own consumption for three months in the year or more."19

The production of surpluses is rare. At face value, this may appear to be the most obvious constraint on the development of agro-processing activity in former bantustan areas, linked in turn to constraints on access to land along with the lack of institutions required to support smallholder agriculture. But, in fact, the dynamics are even more complex than this.

Food production in former bantustan areas takes place within the wider context of the economy as a whole - in particular, in the shadow of a large-scale, vertically-integrated agro-processing sector, that in turn draws on the scale economies arising from the big-farm model that was incentivised and supported for decades in what used to be the white farming sector and is now called the commercial farming sector.

Historically, part of this picture includes the extent to which mining capital invested in consumer goods production during the apartheid years, when foreign exchange controls limited their ability to take capital outside the country and sanctions limited their options there also. Although outside the scope of this article, this trajectory of investment - from mining into maize-meal, sugar, soap and beer - is surely not typical for mining companies in other parts of the world.

As a result of this range of factors, most processed agricultural products are already mass-produced in the core economy. The following list of basic goods and key brand-names and/or owners - instantly recognisable to South African consumers - illustrates the point:

Maize meal (Iwisa, Ace, White Star), bread (Albany, SASKO, Blue Ribbon), sugar (Illovo, Tongaat-Hulett), milk and dairy products (Clover), Dairy Belle), sunflower oil (Nola, Epic), flour (SASKO, Premier Milling), tea (Joko, Glen, Five Roses), coffee (Ricoffy, Frisco), peanut butter (Yum-Yum, Black Cat),margarine (Flora, Rama), beer (South African Breweries), fruit juices (Ceres, Liquifruit, Oros), canned goods (Koo, Gold Crest, All Gold), rice (Tastic), Simba Chips and Coca Cola.

Many other basic non-food items are also mass-produced by recognised brand-names: for example, paraffin, matches, soap, washing-powder, shoe polish, candles, cigarettes, fencing wire and cement bricks. Even school uniforms - grey pants for boys and black tunics for girls - are mass-produced in vertically-integrated supply chains.

To the extent that competition does exist in these product segments, it is typically among a handful of large producers and often takes the form of increasing concentration and vertical integration within each of these, with large volumes enabling low unit margins. This tends to squeeze out even medium-sized competitors, let alone small producers. Brand diversity is also sometimes just a market segmentation strategy within one holding company - such as in relation to beer, where (almost) all brands lead back to SABMiller. There are also multiple cross-holdings among the largest players.

${ }^{19} \mathrm{Du}$ Toit A "Adverse Incorporation and Agrarian Policy in South Africa Or, How Not to Connect the Rural Poor to Growth" Conference Paper (2009). 
Where poor consumers are the target market, price is critical, and mass production processes have advantages over small producers in this respect. In addition, branded goods are attractively packaged, they provide a level of consistency and quality assurance, and advertising reaches all corners of South Africa, targeting all market segments and impacting on aspirations everywhere. Spaza shops in the most remote locations will have Omo, Coke, Iwisa, Rama or other brands, and poor consumers are no less susceptible to the promises of brand-based advertising than rich ones.

In this context the scope for small-scale manufacturing and agro-processing targeting local consumers in poor communities is very limited indeed. This doesn't mean there are no opportunities at all; but those that do exist tend to take the form of niche opportunities rather than opportunities at the kind of scale that can create large numbers of jobs, or the kind of scale required to sustain group projects or co-ops.

The need to create employment at scale often means more people want to participate in group enterprise activities than the enterprise can really sustain - and government support programmes have encouraged this also. This often, however, leads to a mismatch between the scale of output needed to support all the participants and the buying capacity of the local market they are targeting.

\section{A Typical Sewing Co-op}

There are 20 people in the project;

They aim to earn R500 a month.

This means the project must pay R10,000 a month in wages.

Let's say wages are $25 \%$ of the cost of the dresses they make, with materials and other costs making up the rest of the costs.

This means they must sell dresses to the value of R40,000 each month, every month, to break even and pay themselves R500 each. At R100 per dress, they must sell 400 dresses a month. If the dresses cost less, they must sell more.

If the group is reduced to just five members, they must still sell 100 dresses every month to earn R500 each. If they aim to earn R1 000 each, all of these figures must double.

In most poor areas, achieving or sustaining sales at this scale is hard.

While there are often niche opportunities for enterprise activities such as sewing, these can generally support only a few people. The introduction of any level of scale introduces a different level of complexity and requires a degree of market penetration that tends to bring such enterprises into some form of direct competition with established producers and retailers such as Pep Stores or Jet - even in remote areas. 
These are key reasons why small-scale manufacturing and agro-processing take place at such a negligible scale in marginal areas and why there is such a litany of failure for the kinds of projects that so many small enterprise development programmes have favoured, such as mini-bakeries, peanut-butter co-ops, atchar production, poultry abattoirs, piggeries and fence-making projects, to name a few. Often these fledgling enterprises are in fact in raw competition with big capital in the core economy, and it's certainly not a level playing field.

While existing value chains tend to exclude small producers and new entrants, there is still no point setting up parallel production or agro-processing initiatives as if these giants weren't already occupying this market space.

Such approaches assume a dualism in the economy, in which first and second economies are indeed parallel and disconnected when, in fact, they operate within the same economyand within the same market space.

The logic of these strategies is reminiscent of the "core-periphery" debates in development economics: there is an "import substitution" logic to setting up local production facilities to serve the local economy, but the policy options associated with these approaches are not available: there are no tariffs to protect "infant industries" in South Africa's marginal areas, no anti-dumping clauses; our "core and periphery" exist within one economy.

In sum: small-scale producers targeting consumers in local markets have to compete in relation to price, quality, payment terms, packaging and brand recognition. It is widely recognised that this is hard; it is less widely recognised that, often, small-scale production under these conditions simply isn't viable at all, and it will take more than training, entrepreneurial spirit and access to credit to change this reality.

\section{IMPACTS ON SMALL-SCALE SERVICES AND RETAIL ENTERPRISE}

These constraints on small-scale manufacturing have knock-on effects on the services sector.

The fact that services are "non-tradeable" gives them certain advantages which spatial distances potentially reinforce. At one level, the services sector might even be expected to benefit from spatial inequality and its associated distances: if you need your tyre repaired, or your hair cut, or your child cared for, you need it repaired where you are: the fact that it can be repaired more cheaply in the nearest town does not necessarily help you.

However, despite these potential advantages, a part of the services sector involves business. This in turn requires a certain level of demand within a given local economy, with local manufacturing providing part of the market for such services. In the absence of the kind of critical mass required to support business services, the services sector ends up more reliant on personal services than it might otherwise be. At the same time, in a vicious cycle, limits on the dynamism of the business services sector places a further constraint on the scope for all forms of local business development - as well as for smallholder agriculture. 
This is the overall context in which retail activities end up being the dominant form of economic activity in marginal contexts. Far from being a symptom of a lack of entrepreneurship, this actually reflects a sober entrepreneurial assessment of where opportunities really lie; and to a large extent they lie in the distribution of branded goods from the core economy to the margins, in ways that complement and extend existing formal retail networks: through street trading, spaza shops and shebeens.

Informal traders are also rarely a channel for the distribution of goods produced by small or informal enterprise. They are, instead, a complementary distribution mechanism for branded goods - and increasingly, for imported goods; for example, from China. ${ }^{20}$

These informal retail networks in fact provide a significant complementary channel to market for many branded goods targeting poor consumers. However, even these smallscale and/or informal distribution channels currently face increasing levels of competitive pressure as the formal retail sector targets new markets. The impacts of such market penetration in a small rural town in the Eastern Cape are described as follows:

"A particularly ambiguous role is played by the presence in Mount Frere of the giants of South Africa's retail and services sector, particularly of South Africa's major supermarket chains (Spar, Boxer/Pick 'n Pay, and Shoprite). The ability of these supermarkets to provide access to relatively low-priced staples has complex local effects. On one level, this does enable those who have some access to cash to stretch their resources. On another level, their arrival has had profound impacts on the local productive economy. For one thing, the availability of cheap staples reduces the incentives for local agricultural production - not only because own maize is no longer significantly cheaper than store-bought maize, but also because access to store bought maize does not impose the risks imposed on own production by the vagaries of the local climate and the risk of theft. Secondly, the coming of supermarkets has eviscerated the local trading stores that, before retail deregulation, formed the hubs of the local credit economy. Thirdly, local supermarkets compete with small entrepreneurs, squeezing them out of the service economy, while their supply chains bypass local producers." ${ }^{21}$

While it might be assumed that the prevalence of street traders selling fresh produce might provide a "virtuous value chain" linking smallholder farmers to consumers, this is not necessarily the case. In Tshakuma Market in Limpopo, for example, street traders mainly buy their fruit and vegetables from large distributors, because in this way they are able to get a spread of types of produce from one purchase point. These distributors also offer cold storage which allows access to out-of-season produce, and they provide better quality assurance. ${ }^{22}$

Despite real structural constraints, what is remarkable is the often unseen level of initiative and investment in a range of what are often highly marginal activities:

"( $T$ )hese activities often seem simultaneously vital to survival and perilously marginal and fragile. In several cases, informants appeared to rely heavily for their very survival on economic activities that, even after careful probing, seemed to offer only vanishingly small

\footnotetext{
${ }^{20}$ Kimmie, Z \& Ismail, Z "Analysis of Street trading Activities in South Africa" Community Agency for Social Enquiry: Report for the Department of Trade and Industry (2006).

${ }^{21}$ Du Toit, A \& Neves, D (2007) (n 4 above).

22 Charman A \& Peterson L "Making Markets Work for the Poor - Understanding the Informal Economy in Limpopo" Research Report to the Limpopo Centre for Local Economic Development (2008) at 60.
} 
economic rewards: selling a few cooked sheep's heads - which require hours of arduous, dirty, and unpleasant work - for R10 profit a head; selling, by the cupful, paraffin carried kilometres in the hot sun at a profit of a few cents per sale; selling individual pieces of chewing gum or single cigarettes or biscuits for 10c each; helping run a crèche all day, every day, for R200 a month; being paid R10 to R15 for a day's work plastering a mud hut in the Eastern Cape. All these activities seemed barely sustainable or profitable, yet they seemed to be the household's only means of getting their hands on some cash."23

It is because these activities are vital to survival for many households that it really matters to find ways to support them, to address these extreme forms of working poverty, to improve the conditions under which people work and the returns they are able to secure. That is, however, very different from presenting these forms of self-employment as a nascent pathway out of poverty, when current structural constraints mean they are instead a poverty trap.

\section{ALTERNATIVES IN HIGHER VALUE AND HIGHER VOLUME MARKETS}

The focus of the argument so far has primarily been on the limits of manufacturing and agro-processing enterprises targeting poor consumers in local markets. Despite the bleak picture painted, there are nevertheless always some opportunities at this level; and the conditions described are not immutable - the point is to understand them in order to change them. In addition, the "local production for local consumption" model discussed so far is not the only enterprise development strategy open to entrepreneurs in these areas and, in response to the constraints described, enterprise development strategies have increasingly focused on these alternatives.

Perhaps the most obvious alternative is simply to stay out of manufacturing altogether and to focus on retail or service activity. Statistics show us this is exactly what most small and informal enterprises are doing - although with services still trailing behind retail activity by a wide margin, with a bias to personal services.

Within manufacturing and agro-processing, however, there are two main trends in the kinds of alternative strategies pursued:

- Strategies to enable participation in existing, high-volume value chains.

- Strategies that enable access into higher-value, niche markets, usually targeting consumers with greater disposable income, outside the immediate local economy.

- Strategies to supply large retail chains.

\subsection{Access to high-volume, low mark-up value chains}

Many strategies have focussed on supporting small and/or black producers to gain access to the vertically-integrated agro-processing value chains that already exist, such as for sugar, beans, timber or horticultural products. These markets tend to require large

${ }^{23}$ Du Toit \& Neves (2007) (n 4 above). 
volumes and offer low mark-ups. ${ }^{24}$ As a consequence, participation by small producers in these value chains generally requires forms of co-ordination to consolidate product and to achieve the minimum volumes required.

While there is clearly an opportunity for forms of co-operatives to provide such coordination, the initiative to do so has thus far largely tended to come from "above" - from agro-processing companies in the relevant sectors, through outgrower schemes.

In vertically-integrated value-chains - in which the company at the top of the chain owns the companies further down - there is a tendency for profit to be concentrated at the top of the chain, with the activities of its subsidiaries performed at very low margins or even at cost to contribute to profit maximisation at the centre.

This can make it extremely difficult for small enterprises to compete at lower levels (or any level) in the value chain. Even where companies do outsource services at the local level, this value-chain structure can mean the cost benchmark against which local companies have to compete is very low. In agriculture, margins at the farm gate are notoriously low too.

Strategies to enhance access to such value chains may result in improvements in incomes at local level as a result of the increase in volumes supplied, despite the low markups. This is an important outcome in a context of limited alternatives - but unless issues of power and the distribution of value are also tackled, participation of this kind can end up simply reproducing existing patterns of distribution between the core and the margins, albeit on a wider scale. The crucial strategic issue is how to change the spread of benefits and returns within such existing value chains, to avoid this being simply another form of "adverse incorporation."

Access to such markets also requires an understanding of how "modern markets" are changing. Lowitt summarises the following trends in lead firm behaviour in South Africa:

“(1) (L)ead firms are increasingly demanding ever larger volumes from suppliers, (2) lead firms are increasingly shifting away from being resellers of other enterprises products and producing their own brands and private labels as a means of market differentiation, (3) concentration at lead firm level has been cascading down value chains so that all points along a chain are visibly more concentrated than previously, in addition, the number of hand over points in chains are decreasing and lead firms are delegating additional activities to main suppliers, (4) standards are becoming increasingly important along value chains and lead firms are relying on codification and certification to decrease governance costs, and finally, (5) profits and returns along chains are increasingly gravitating towards logistics, branding, marketing and design activities and away from production activities. These five key observed behaviours create an infertile and hostile environment for small producers seeking access to modern market value chains." 25

\footnotetext{
${ }^{24}$ Lowitt, S. "New Ideas to Systemically Link Small and Marginalised Producers to External Markets Using Value Chain Analysis" Second Economy Strategy Project, TIPS (2008).

${ }^{25}$ Lowitt S. (2010) (n 24 above).
} 


\subsection{Targeting higher-value, lower-volume niche markets}

Enterprise development strategies have also tried to identify higher-value niche products aimed at markets with more disposable income, such as in the tourism sector, in urban centres, through national retail outlets or in export markets. This includes, for example, strategies around designer craft, essential oils, mushrooms, snails, goats' milk cheese, rooibos tea and trout-farming. These enterprises generally produce relatively small volumes and need higher mark-ups to be viable.

A key constraint for enterprise development strategies focused on these kinds of highvalue, niche products is that the entrepreneurs - or group participants - are targeting consumers in markets that are often outside their own experience and often also in a different geographical location; thus, "external" markets in both respects. They are therefore often unfamiliar with the "value proposition" in the market they are targeting: they may not be consumers of goats' milk cheese or snails and, for example, the kinds of rapidly-changing design aesthetics in the craft sector have been a challenge for many craft producers. This typically means that, in order to succeed, enterprises targeting high-value niche markets require far higher levels of mentorship, and also of intermediation, to bridge the gap and provide market insights and access to external markets of these kinds.

\subsection{Access to supermarkets and retail distribution systems}

Many of the large supermarkets use central procurement systems, with their local branches obliged to carry stock provided through this mechanism regardless of the scope to procure from local producers. Minimum volume requirements mean co-operation is often needed between small producers; becoming an accredited supplier can entail complex compliance issues, stringent quality assurance and rigid delivery requirements.

There are, however, also instances where supermarkets have set up local procurement systems providing significant opportunities for local smallholder farmers; for example, Spar in Thohoyandou, creating new market opportunities for smallholder producers. ${ }^{26}$

\subsection{Access to Wider Markets means an end to Informality}

Whether producers are aiming for higher volume markets, higher value markets, or access to the retail chains, these strategies all entail being part of wider value chains and "external" markets, and involve a shift away from "face to face" transactions to "business to business" transactions. This brings new challenges and different conditions for success. In particular, it signals an end to informality and requires a step-change in the level of business sophistication. The barriers to entry are far higher.

The key driver of the "end to informality" is that demonstrating the capacity to conform to accepted business practices - regulatory and otherwise - becomes a necessary condition for securing business contracts in this environment.

${ }^{26}$ Jacobs P "Market Development and Smallholder Farmers: A Selective Literature Survey" HSRC-CPEG (2008) for the Second Economy Strategy Project, TIPS. 
As soon as a transaction is no longer face to face and immediate, it requires greater formality because it requires an enforceable contract to govern the exchange. This includes, at a minimum, a mechanism to place a formal order specifying what is being bought, an invoice, the ability to issue a receipt, a bank account and an address. Today, a cell phone number and e-mail address are probably key too. Without an invoice, for example, a formal business can't "recognise" the transaction in its books, because neither its auditors nor the South African Revenue Service will do so.

The critical issue, however, is contract security. As the value of orders rises, so do the risks for both parties. For small enterprises, large orders mean significant risk: what if the order is produced but the buyer fails to pay? For the buyer, however, the risks of making an advance-payment to an informal entity are generally too great: because, if the supplier fails to deliver, there is no contractual recourse for any advance paid. Insurance against such risk also requires levels of formality.

These transactions also require greater quality consistency. In the informal economy, what you see is what you get; but, when a buyer places an order on the basis of samples or against specifications they have provided, they expect the product they receive to match the product they ordered.

Even in "niche" markets, access into external markets can create massive increases in volume requirements. For example, when the Spanish department store Il Corte Inglese decided to order beaded bracelets from craft producer "Gone Rural", it ordered 17,000 bracelets. It took 200 beadworkers to deliver the order, and the entrepreneur who secured the order had to take a mortgage on his house to fund the beads. While this represents significant opportunity, it also entails increased risk: it requires more capital and capacity, and greater contract security (and therefore formality), for both parties. ${ }^{27}$

Private standards are also increasingly applied in this context. Large buyers, in value chains of many different types, want the contents and origins of what they buy to be certified and verified, introducing new levels of complexity. If there is export involved even if this takes place much further up the value chain - compliance with a range of phytosanitary and other standards is required, particularly for food products.

In the craft sector much emphasis has been placed on creating access into export markets. Here is an example of what that can mean in practise:

"Going into the US market, any item has to be labelled "Handmade in South Africa". For every article that is not labelled, Customs will impose a fine, and they will flag that importer, which will result in every shipment of theirs that comes in being stopped and searched. There's a searching fee involved, and a time delay involved....

“In addition, every time a shipment goes in, there's a $\$ 250$ customs fee for checking it. So this also means that for an importer, consolidation of product is vital. The more product you can include in a shipment, the lower your unit cost for each item.

"Then, the way you explain the product on the invoice affects whether it is dutiable or not. For example, a cushion cover could go in at $0 \%$ or $26 \%$ or $55 \%$ duty: depending on how it's worded,

${ }^{27}$ Philip, TK "Enterprise on the Margins: Making Markets work for the Poor?" (2007) PhD Thesis, University of the Witwatersrand. 
what code it's given, what category it goes into. You've got to do that homework here: it's up to us here.

"You also need to know: do you need a certificate of origin for your product? If you need one, you've got to ensure that it's done correctly. With skins for example, it's got to have a veterinary certificate, a certificate proving that the skin used in the product was got legally, it wasn't poached, it wasn't this, it wasn't that. If there are feathers on the product, it could be a problem with Food and Wildlife..."28

In sum, access to "external" markets - near and far - typically involves participation in business to business transactions and/or wider value chains. This opens significant new levels of opportunity, but also requires levels of compliance with a combination of regulation, institutionalised business practices and private standards. A key driver of this process is the need for increased contract security and risk mitigation as the stakes rise, not only for the producers but also for those with whom they are transacting. The greater the level of compliance with accepted business practice, quality standards and regulation, the less risk and more contractual certainty exists for buyers, and the more likely they are to buy.

The business incentives driving formalisation processes tend to get overlooked in a rather narrow debate that treats all regulation applied to the small enterprise sector as "red tape". Of course, regulation must serve a social or economic purpose and be efficiently implemented. But no matter how simple registration processes become, small businesses trying to access these markets cannot escape from grappling with complex standards and compliance issues - many of which are imposed by buyers rather than being statutory.

These are "the rules of the game" for small enterprises seeking access to wider value chains or business to business transactions; access to the opportunities in these markets means playing by these rules. Reducing red tape is therefore only one part of the equation; the other part must be to assist small businesses to raise their game.

\section{WHAT ABOUT URBAN AREAS?}

The analysis in the previous sections has focused mainly on the dynamics affecting rural areas, and the former bantustans in particular. Many similar dynamics affect small enterprise in urban areas, although there are key differences. At one level, there is even less scope for small-scale manufacturing targeting poor consumers, because "big" manufacturing and "big" retail quite unambiguously occupy this market space. At the same time, however, markets are far larger, deeper and more diverse; there is far more disposable income, and population densities coupled with greater economic dynamism create more scope for services. Yet the sector is still dominated by retail activity.

Key trends in the urban sector were illustrated by the Finscope Small Business Survey in Gauteng in 2006; the typical characteristics and patterns of growth seen in this sector have implications for its potential to create jobs. The following graph, drawn from data in the

\footnotetext{
28 Interview with craft exporter Eugenie Drakes (2002), quoted in Philip (2007) (n 14 above).
} 
FinScope Small Business Survey, Gauteng, shows the number of jobs created by different enterprise types across the spectrum of levels of business sophistication:

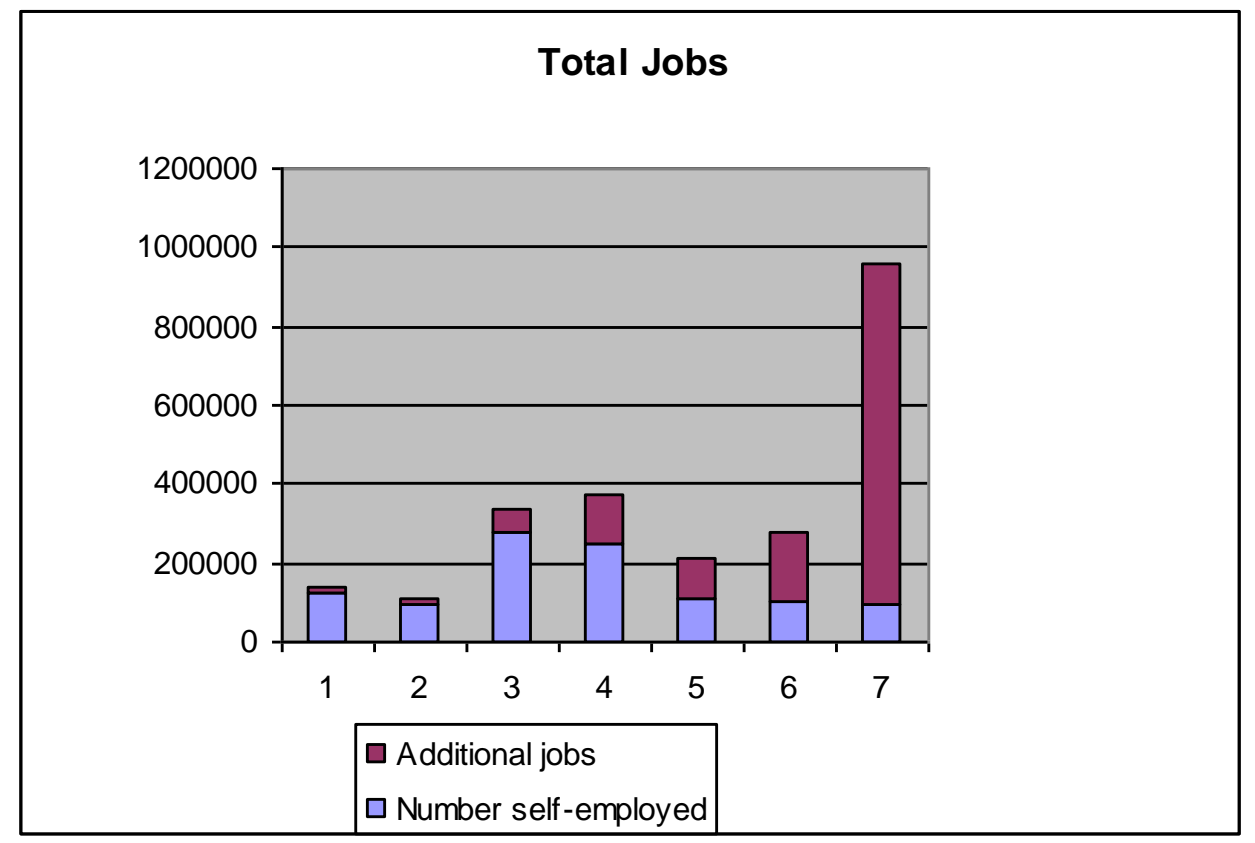

Figure 2: Job Creation in Small Businesses: Data extracted from FinScope Small Business Pilot Survey: Gauteng 2006: using Finscope's Business Sophistication Measure from $1-7$.

FinScope's "Business Sophistication Measure" (BSM) classifies enterprises across a spectrum from BSM 1 - the most marginal and informal - to BSM 7, which is the most sophisticated end of the small enterprise spectrum. The graph shows the number of ownerentrepreneurs and the number of additional people they employed at the time of the interview. BSM 1-5 is strongly dominated by retail activity, with an increasing contribution from services. BSM 6-7 sees the balance tip towards services, including self-employed professionals such as in medical practices and construction. Even in BSM 7 manufacturing constitutes only $5 \%$ of the total. Data illustrating enterprise turnovers follows a similar pattern, and if profit constitutes $20 \%$ of turnover (a highly optimistic estimate), then even in BSM 6 average earnings are only R1 100 a month, highlighting again just how survivalist such enterprises are.

The usual conclusion drawn from the exponential increase in job creation and turnover results at the top end of the continuum is that this is a consequence of formalisation and that the focus of strategy should therefore be on removing barriers to formalisation, to unlock job creation and improved business returns.

However, this overlooks the critical issue of how these enterprises are inserted into markets. So, for the largely informal retail enterprises in BSM 1-5 the opportunities to go "up the ladder" to BSM 7 are very limited and formalisation will not change that. There may be scope for street-traders to start spaza shops, and for spazas to carry more stock, but neither of these strategies require formalisation, and the scope for growth and to climb "up the ladder" into the formal sector is highly constrained. 
Instead, "big retail" is coming down the ladder, penetrating ever further into the markets which informal retailers still occupy. For informal sector traders the incentives to formalise remain very limited: they transact directly with the end user, volumes per transaction are low, they are largely involved in cash sales, and there is no contractual relationship beyond a once-off exchange.

In fact, according to the Finscope survey, 96 percent of the customers of all small enterprises are private individuals, with the vast majority of businesses relying on direct sales to the end consumer. It is only in BSM 6 and 7 that the client base changes to involve business to business transactions and participation in wider value chains. ${ }^{29}$ Associated with this is larger turnovers, more scope for employment creation - and greater risk.

So, rather than formalisation catalysing an exponential shift in opportunities, the opportunities are instead a consequence of the way in which the business is inserted into markets - the need to formalise follows from this, and it is a necessary condition for grasping such opportunities, but it is not "formalisation" per se that makes the difference.

\section{A FOCUS ON STREET-TRADERS}

Despite plenty of evidence of dynamic and entrepreneurial responses amongst street traders, the informal sector and survivalist enterprise, these illustrate rather than negate the wider arguments. Research in this area confirms that successful informal entrepreneurs in a range of contexts tend to grow their businesses "sideways" - spinning off new and complementary micro-activities - rather than growing "vertically" to become bigger and more formal or "graduate". Charman and Peterson provide the example of a butchery in Khayelitsha that created opportunities for three other micro-enterprises: the first set up braai facilities, this created demand for liquor sales, and finally a car-wash began for those braaiing their meat and having a drink. ${ }^{30}$ This example of opportunities being "crowded in" applies at scale in street-trader markets: "[c]oncerns about overtrading need to off-set by an understanding that the intensity of trade in a given area generates additional opportunities: for diversification, for services." ${ }^{31}$

Charman and Peterson also illustrate the creativity of informal entrepreneurs in differentiating their products to secure market share - such as the street trader with a loyal following who mixes different flavours of Simba Chips to create new combinations. Entrepreneurial as it is, it is equally an illustration of the deeply dependent relationship of such activity to mass-produced consumer goods, and highlights again the extent to which opportunities are limited to distribution from the core - even where this entails some product differentiation on the way. Subsequent to Charman's use of this case study in his work, Simba launched a new range of "mixed flavour" chips. Whether inspired by this street-trader's entrepreneurship or not is hard to tell; but, even if it was, her ability to lay claim to any kind of intellectual ownership of this innovation is non-existent. It is just

\footnotetext{
${ }^{29}$ FinScope Small Business Pilot Survey: Gauteng 2006 at 37.

30 Charman \& Peterson (2007) (n 22 above).

31 Second Economy Strategy Project "Summary of Outcomes of Workshop to Review Research on Street Trader and the Micro-Enterprise Sector: Testing the Consensus" PowerPoint presentation (2008).
} 
another example of the fact that, to the extent that there is wealth at the bottom of the pyramid, the real problem is how to keep it there.

\section{SOME IMPLICATIONS FOR STRATEGY}

South Africa's high levels of structural inequality bedevil the best efforts of development strategy and limit the development options available. While inequality in human resource development has been an explicit focus of post-apartheid strategy, there has been less focus on the way spatial inequality and the structure of the economy reproduce economic marginalisation.

The combined effect of South Africa's spatial inequality and the structure of its economy have produced a negative "double whammy" in development terms: the former has significantly constrained the scope for land-based livelihoods to provide a form of safetynet for poor people in rural areas, while the structure of the economy severely limits the potential for self-employment or informal sector activity. Strategies that assume that poor people can "self-employ" their way out of poverty are misplaced; under current conditions self-employment is a poverty trap for many, and solutions to South Africa's unemployment problems are unlikely to come from here. This shifts the burden of focusing on employment creation back into industrial policy and growth strategy: which is what the New Growth Path $^{32}$ starts to do.

The structural constraints on livelihood and enterprise activity in marginal contexts mean that poor people in South Africa are unusually dependent on either social grants or wages, directly or through remittances. This dependence is deeply structural. It is not a problem that can be fixed with a change of attitudes, but decades of such structural dependence have certainly taking a toll on people's sense of economic agency: their ability to change their material conditions and improve their quality of life through their own actions.

To compound matters, while social grants certainly play a key role in reducing poverty, there is nevertheless a glaring social protection gap: apart from short-term unemployment insurance (UIF) for those who have previously held formal-sector jobs, there is simply no form of social protection for the unemployed - for people who are willing and able to work but unable to find any. This large sector of the population has little choice but to depend on "goodwill" transfers from others; from people who are employed or have access to social grants. The social dimensions of such economic dependence make this doubly disempowering. This disempowerment has its own sets of negative social consequences.

This burden of providing financial support to the unemployed falls unevenly on poor communities, with wage-earners and social grant recipients supporting an increasing

\footnotetext{
32 Economic policy announced by Economic Development Minister Ebrahim Patel in December 2010, aimed at creating 5 million new jobs by 2020: see "The New Growth Path: The Framework" at http://www.info.gov.za/ view/DownloadFileAction?id=135748 (accessed 11 June 2011). For discussion, see International Labour Organisation "South African New Growth Path sets ambitious target to create 5 million jobs by 2020" at http://www.ilo.org/jobspact/news/lang--en/WCMS 151955/index.htm (accessed 11 June 2011) - Editor.
} 
number of dependents. A significant part of the costs of unemployment are therefore carried by wage-earners from poor communities. The net effect of this is that the costs of unemployment have become - in part at least - an indirect "wage-cost" rather than being absorbed as part of the social wage.

Workers in particular and poor communities in general also carry an uneven burden in relation to the costs of spatial inequality, translated into the cost of transport. In both these instances, wider social costs are being transmitted into the cost of labour rather than being treated as social costs. This adds to wage pressures and raises the cost of labour, which in turn reduces incentives for labour-intensity at a wider level in the economy. The fact that these costs are carried disproportionately by poor communities also has further disequalising effects at a societal level, in a society already so unequal.

The development of a strategy to tackle structural inequality is a crucial priority for a development agenda in South Africa. While the New Growth Path starts to address aspects of this challenge, the kind of over-arching strategic vision and long-term strategy required should also fit squarely within the mandate of the National Planning Commission.

For the purpose of this article, the focus now turns to the implications of the analysis presented for strategies to improve economic opportunities on the margins.

The first key point is that such strategies need to look at the economy as a whole; linking competition policy, industrial policy and small enterprise development strategies to focus on the spread of power and benefits in value chains, as well as issues of market access for small enterprise. Within this, the strategic challenge is to identify the kinds of instruments able to effect shifts in access and distribution within value chains and how to achieve this at a systemic level. This will not be an easy task, but work by Sandy Lowitt explores some ways in which it could be done. She draws on the example of the European Union's "LEADER" programme to examine the instruments available to government to influence the buying behaviour of the big retailers; for example, through the use tax incentives and adaptations of the Black Economic Empowerment codes to focus on procurement from small producers. The emphasis is on the carrot, not the stick. ${ }^{33}$

Addressing the distribution of power and value in value-chains also requires a different approach to transformation, looking more seriously at issues of access - including access to ownership - at all levels of the chain and the scope to re-negotiate the spread of benefits along the chain as a whole. Many of the companies that are "lead firms" in the South African context are currently undergoing transformation processes or facing pressure to do so. Such processes often interpret transformation narrowly as a change in the patterns of racial ownership and management at the top. Such shifts in ownership are an important component of overall transformation, but the way in which many black economic empowerment deals have been structured means that the beneficiaries of these deals have taken loans to purchase shares and have to pay these loans with dividends. This has the perverse effect of intensifying the incentives to concentrate profit at the centre, to the detriment of opportunities for small enterprise participation further down the chain.

Specific opportunities exist in relation to land restitution processes, where large parcels of land are currently under claim in the forestry, sugar and fruit sectors. Many jobs depend

${ }^{33}$ Lowitt, S (2010) (n 24 above). 
on the outcomes of these processes - not just on the land, but all the way up the value chain. In most agro-processing value chains relatively little value is located on the land itself any more; the opportunity therefore needs to be taken to think beyond land alone in the resolution of these claims, in ways that secure the jobs across the length of this chain and, in the process, to find ways to transform the distribution of ownership and of returns across the full length of such chains also.

The analysis above has highlighted the "step-change" in skills involved in targeting wider markets. As a consequence, strategies are needed to bridge the gap between marginalised producers and wider markets, including the scope for different forms of intermediation. While non-profit support institutions often facilitate access to wider markets, and some do it well (although others do it badly), there is also scope for marketbased, private sector roleplayers to bridge this gap.

Von Broembsen identifies the challenge as follows:

"to explore how an enabling institutional and legal environment could be created for intermediaries, without creating opportunities for exploitation; and at the same time improving informal workers' earnings and conditions of work, or put differently, to pursue a 'decent work' agenda. "34

Such strategies include creating economies of scale on both the demand and/or supply sides, to give poor producers greater collective market power in value chains, and to achieve the minimum supply volumes required for participation, negotiate improved levels of market access and/or better terms of participation. These functions can be provided, for example, by input supply and marketing co-ops for small-scale farmers, shared transport arrangements, cropping associations or tractor hire. These forms of co-op have a high success rate all over the world, but have not been a big focus of co-op strategy in South Africa.

There are also other instruments to achieve economies of scale in a range of ways that include business hubs and industrial or sectoral "cluster" approaches - even though the latter may be most applicable to the more advanced end of the small enterprise sector.

"Intermediation" can take other forms, however, and these roles can also be performed by private companies that bridge the gap by consolidating produce from many small producers and may provide market information and other services in ways that add value rather being simply a form of exploitation. The existence of marketing agents contracted and paid on commission by producers - rather than being an agent for the buyer - also introduces a different power relationship. ${ }^{35}$ Such "intermediary" functions can become part of the functioning of a value chain and may in many instance be a necessary condition enabling market access.

These areas for strategy development are all oriented to facilitating access into wider markets. Yet, for many of the most marginal enterprises, this is not a feasible trajectory. For this large segment of the micro-enterprise sector the constraints are so high that more

\footnotetext{
34 Von Broembsen, M "Mediating from the margins: The role of intermediaries in facilitating participation in formal markets by poor producers and users" (2011).

35 Von Broembsen, M (2011) (n 34 above).
} 
caution needs to be exercised in promoting self-employment as a solution for all. Strategies need to move away from using the number of start-ups as the benchmark for success and to focus instead on the "patient support" needed to turn start-ups into "stay-ups"; to focus on improving the survival rate and the returns to participants, and to increase the impacts of such activity on poverty.

For street traders, Skinner argues that one of the most pressing issues is to establish clear "rules of the game" to reduce their risks and vulnerability to abuse in an unclear regulatory environment. For street traders, access to pedestrian traffic is vital: at transport nodes as well as public facilities such as hospitals or the Department of Home Affairs. Building "stalls" at a distance from such traffic flows destroys rather than supports this sector.$^{36}$ Counter-intuitive as it may be, street traders also manage to do good trade outside large shopping malls. Enabling these forms of access is an issue for town planning as well as transport planning. How, for example, have street traders been accommodated in the design of Rea Vaya ${ }^{37}$ facilities?

For street traders, lack of storage facilities means they can only carry as much stock as they can (literally) carry. Access to "lock up and go" facilities changes this, enabling diversification and growth at this level. Access to ablution facilities and running water would significantly improve their working conditions. Charman and Peterson also highlight the extent to which provision of electricity supply points - on a "pay as you go" basis would transform the enterprise options available to street traders and street-services. Finally, street-traders can also use forms of cooperation and organisation to reduce their costs and increase their "voice".

These strategies are all focused on improving outcomes for entrepreneurs in markets and this certainly matters. But strategies to address economic marginalisation cannot end there, in a context in which market access is so constrained that large numbers of people are effectively locked out of opportunities for market-based employment or selfemployment. The final area for policy innovation highlighted here is therefore the need for strategies that enable economic participation even where markets don't.

This is an area for policy innovation. At present, in South Africa, large numbers of unemployed people depend on indirect "goodwill" support from social grants actually meant to serve other purposes; yet even where such people do manage to engage in market-based activity - despite the odds - the returns are too often too low to lift them out of poverty. There is an intermediate level of support required and, although another social grant would certainly help, it's not just about the money. It's also about the dire need to reignite people's sense of economic agency, to enable people who are locked out of productive opportunities to experience the dignity of labour - certainly the most powerful antidote to "dependency," structural or otherwise - and to rebuild a culture of work. For the society and the economy, it is also about unlocking vast amounts of under-utilised labour power to contribute to growth, to development and to addressing South Africa's many social challenges.

\footnotetext{
${ }^{36}$ Skinner, C. Presentation prepared for the Second Economy Strategy Project, 2008

37 That is, the Bus Rapid Transit System in the City of Johannesburg - Editor.
} 
The most obvious instrument in this regard is through public employment. While South Africa has an existing policy commitment in this regard, the Expanded Public Works Programme (EPWP) has faced a range of constraints significantly limiting its scale and scope relative to the scale of demand. This was the context in which the Second Economy Strategy Project initiated the Community Work Programme as a new component of EPWP: to explore new ways of taking public employment to scale.

The Community Work Programme has a number of features that differentiate it from other public employment programmes in three key respects. Firstly, it offers two days of work a week or eight days a month. The rationale for this model is that, in a context of structural unemployment, the priority is to offer regular and predictable access to a minimum level of part-time work on an ongoing basis, rather than full-time but finite access to a work opportunity that will come and go, without any lasting impact on poverty. The second key feature of the Community Work Programme is that the work to be done is decided at community level: it must be "useful work" that contributes to the public good, and it must be delivered with a 65 percent labour intensity ratio, but it is left to communities to prioritise their needs.

Thirdly, while the CWP is a government programme, it implemented by non-profit entities at the local level. ${ }^{38}$

The Community Work Programme was also designed to look at the scope to adapt the concept of a minimum employment guarantee introduced in India, where the Mahatma Gandhi National Rural Employment Guarantee Act guarantees a minimum of a hundred days of employment per annum to rural households that need it. This gives new materiality to the concept of a right to work - a policy concept of obvious interest for South Africa.

\footnotetext{
38 For more information on the Community Work Programme, see Philip "Towards a Right to Work: the Rationale for an Employment Guarantee in South Africa" TIPS (2010) at http://www.tips.org.za/node/1993 (accessed 11 June 2011).
} 


\section{Bibliography}

Aliber, M., de Swardt, C., du Toit, A., Mbhele T. \& Mthethwa T. Trends and Policy Challenges in the Rural Economy, HRSC Press (2005).

Charman, A. \& Peterson, L. "Making Markets Work for the Poor - Understanding the Informal Economy in Limpopo" Research Report to the Limpopo Centre for Local Economic Development (2008).

Charman, A., Peterson, L., Simons, M., Dude, T. \& Davids, A. "Informal Economy Study: Trade Component" Final Report for Provincial Government of the Western Cape Department of Economic Development and Tourism DEDT Western Cape (2007).

Devey, R., Skinner, C. \& Valodia, I. "Second Best? Trends and Linkages in the Informal Economy in South Africa" Working Paper 06/102 Development Policy Research Unit, University of Cape Town (2006).

Devey, R. \& Valodia, I. "Formal-informal economy linkages: what implications for poverty in South Africa?" PLAAS Working Paper 8 (2009).

$\mathrm{Du}$ Toit A. "Adverse Incorporation and Agrarian Policy in South Africa Or, How Not to Connect the Rural Poor to Growth" (2009) Paper presented at BASIS conference entitled Escaping Poverty Traps: Connecting the Chronically Poor to Economic Growth in Washington, D.C., 26-27 February 2009 available at http://www.basis.wisc.edu/ ept/dutoitpaper.pdf (accessed 11 June 2011).

Du Toit A \& Neves D. "In Search of South Africa's Second Economy" (2007) 37(2) Africanus 145.

FinMark Trust "FinScope Small Business Pilot Survey Gauteng" (2006) at www.finmarktrust.org.za (accessed 1 March 2011).

FinMark Trust "Finscope South Africa Small Business Survey 2010" at http://www.finmarktrust.org.za/pages/Research-and-Publications/ResearchReports.aspx?randomID=1872482a-81cb-4d6b-82ef-98c524fd0400\&linkPath=7\&lID=7 1\&RandomID=8d3d75f5-1fc9-4b74-aa67-1754dfa8dbc6 (accessed 11 June 2011).

Hickey S, \& Du Toit A. "Adverse-Incorporation, Social Exclusion and Chronic Poverty". CPRC Working Paper 81. Manchester: IDPM (2007).

Jacobs, P. "Market Development and Smallholder Farmers: A Selective Literature Survey" HSRC-CPEG for the Second Economy Strategy Project, Trade and Industrial Policy Strategies (2008).

Kimmie, Z. \& Ismail, Z. "Analysis of Street trading Activities in South Africa" Community Agency for Social Enquiry: Report for the Department of Trade and Industry (2006).

Legassick, M. "South Africa: Capital Accumulation and Violence" (1974) 3 (3) Economy and Society. 
Lowitt, S. "New Ideas to Systemically Link Small and Marginalised Producers to External Markets Using Value Chain Analysis" Second Economy Strategy Project, Trade and Industrial Policy Strategies (2008).

Marais, L. "Missing the Target: Business Development Support to the Second Economy" (2008) Second Economy Strategy Project: unpublished paper at http:// www.tips.org.za/publication/missing-target-business-development-support-secondeconomy (accessed 11 June 2011)

Martins, JH "Household Cash Expenditure by Livings Standards Measure Group" (2006) 34 Journal of Family Ecology and Consumer Sciences 1.

Philip, TK “Enterprise on the Margins: Making Markets work for the Poor?" PhD Thesis, University of the Witwatersrand (2007).

Philip, K. \& Hassen, E. "The Review of Second Economy Programmes: An Overview for the Presidency's Fifteen Year Review" (2008).

Philip, K "Inequality and Economic Marginalisation" Presentation to PLAAS Conference Working On the Margins 26-27 March 2009.

Philip, K "Second Economy Strategy: Addressing Inequality and Economic Marginalisation" (2010) 37 New Agenda, Institute for African Alternatives, Cape Town.

Philip, K "Towards a Right to Work: the Rationale for an Employment Guarantee in South Africa" Trade and Industrial Policy Strategies (2010) at at http://www.tips.org.za/node/1993 (accessed 11 June 2011).

Republic of South Africa "Background Document: A catalyst for accelerated and shared growth - South Africa (ASGISA)" Media briefing by Deputy President Phumzile MlamboNgcuka, 6 February. Office of the President, Pretoria (2006).

Second Economy Strategy Project: "Second Economy Strategy: Addressing Inequality and Economic Marginalisation: A Strategic Framework" (2009), Trade and Industrial Policy Strategies at http://www.tips.org.za/event/second-economy-strategy-addressinginequality-and-economic-marginalisation (accessed 11 June 2011).

Second Economy Strategy Project. "Summary of Outcomes of Workshop to Review Research on Street Trader and the Micro-Enterprise Sector: Testing the Consensus" PowerPoint presentation (2008).

Statistics South Africa "Quarterly Labour Force Survey, Quarter 4, 2010" at at http://www.statssa.gov.za/qlfs/index.asp (accessed 11 June 2011).

Tregenna, F \& Tsela, M. "Inequality, Unemployment and Poverty in South Africa" Second Economy Strategy Project, Trade and Industrial Policy Strategies (2009) at http://www.tips.org.za/files/presentations/Inequality Unemployment and Poverty.pdf (accessed 11 June 2011).

Valodia, I. "Understanding Formal-informal Economy Linkages" Draft Human Sciences Research Council and School of Development Studies, University of KwaZulu-Natal (2006). 
Tregurtha, N. "Review of Siyakhula Massive Crop Production Programme" (2009) Second Economy Strategy Project (2009) at http://www.tips.org.za/node/1549 (accessed 11 June 2011).

Valodia, I., Davies, R., Altman, M. \& Thurlow, J. "Economic Behaviour in South Africa's Informal Economy" Human Sciences Research Council (2007).

Von Broembson, M. "SMME's, the Informal Sector and the 'Second Economy'” PLAAS Working Paper 10 (2008).

Von Broembsen, M. "Mediating from the margins: The role of intermediaries in facilitating participation in formal markets by poor producers and users" Trade and Industrial Policy Strategies (2011).

Von Holdt, K. \& Webster, E. "Work Restructuring and the Crisis of Social Reproduction: A Southern Perspective" in Webster, E. and Von Holdt, K (eds) Beyond the Apartheid Workplace: Studies in Transition University of KwaZulu-Natal Press (2005).

Wolpe, H. "Capitalism and Cheap Labour Power in South Africa: From Segregation to Apartheid" (1972) 1 (4) Economy and Society.

Wray, L.R. "The Employer of Last Resort Programme: Could it work for developing countries?" Economic and Labour Market Papers International Labour Office, Geneva (2007). 